\title{
The Role of Endotoxin during Typhoid Fever and Tularemia in Man. II. Altered Cardiovascular Responses to Catecholamines *
}

\author{
Sheldon E. Greisman, $\dagger$ Richard B. Hornick, Frank A. Carozza, Jr., and \\ THEODORE E. WOODWARD \\ (From the Departments of Medicine and Physiology, University of Maryland School of \\ Medicine, Baltimore, Md.)
}

Since 1959, studies of tularemia and typhoid fever during vaccine trials have led to reproducible clinical forms of the disease in man (1). Such clinical models have permitted observations of a variety of physiologic parameters in the same subject before, during, and after infection and have provided a unique opportunity to evaluate the role of endotoxin in the pathogenesis of these illnesses. Previously (2), the acquisition of significant tolerance to the pyrogenic activity of bacterial endotoxins was described in volunteers convalescent from induced typhoid fever and tularemia. In contrast, no tolerance was acquired after infection with the viral agent of sandfly fever. These findings suggested the release of physiologically active quantities of circulating endotoxin during human typhoid fever and tularemia. The present study is a continuation of such investigations designed to evaluate the role of endotoxin in mediating the pathophysiologic derangements during gram-negative bacterial infections in man.

The introduction of bacterial endotoxins into the blood stream of man and other mammals results in profound alterations in circulatory homeostasis (3). Although the manner of mediation of such disturbances is uncertain, alterations in vascular reactivity to catecholamines may constitute one important mechanism. In the intact rabbit and rat, marked hyperreactivity of the cutaneous

* Submitted for publication November 19, 1963; accepted January 15, 1964.

Suported by the Commission on Epidemiological Survey of the Armed Forces Epidemiological Board and the International Center for Medical Research and Training Program, U. S. Public Health Service research grant E 4162.

† Recipient of Career Development Award from the National Institutes of Health under contract HE-K3-15, 237-C3. and mesenteric vascular beds develops to local application of catecholamines after an initial intravenous injection of a variety of endotoxin preparations (4-6). Similarly, the systemic arterial pressor responses to intravenous catecholamines are significantly enhanced (7). Such cardiovascular hyperreactivity is sufficiently characteristic and reproducible to serve as a bioassay system for endotoxin. Moreover, such a bioassay system can detect small quantities of endotoxin; in the rabbit, $1 \mu \mathrm{g}$ of intravenously injected endotoxin can sensitize the cutaneous vascular bed to the hemorrhagic inducing effect of catecholamines given intradermally $(4,8,9)$. Since endotoxins produce such profound alterations in reactivity to catecholamines, cardiovascular reactivity was assessed before and during human infections induced with Salmonella typhosa and Pasteurella tularense. Control studies were performed during sandfly fever infection, since this illness represents a febrile disease in which endotoxin presumably does not participate.

\section{Methods and Materials}

The volunteers employed, the nature of the infectious agents, and the clinical course of typhoid fever, tularemia, and sandfly fever have been described in the preceding paper (2). All syringes and needles were preheated in a dry air oven at $180^{\circ} \mathrm{C}$ overnight to eliminate extraneous pyrogenic contamination.

Assay of cardiovascular reactivity to catecholamines. All volunteers were hospitalized before the induction of infectious illness. Base-line control responses to iv infusions of $l$-norepinephrine ${ }^{1}$ were obtained after the subjects had been confined to bed and covered with a light blanket. Each test was begun between 9 and 10 a.m. An iv infusion of pyrogen-free physiologic saline was initiated in an antecubital vein. Blood pressure in the

${ }^{1}$ Bitartrate salt supplied by Winthrop Laboratories, New York, N. Y. 


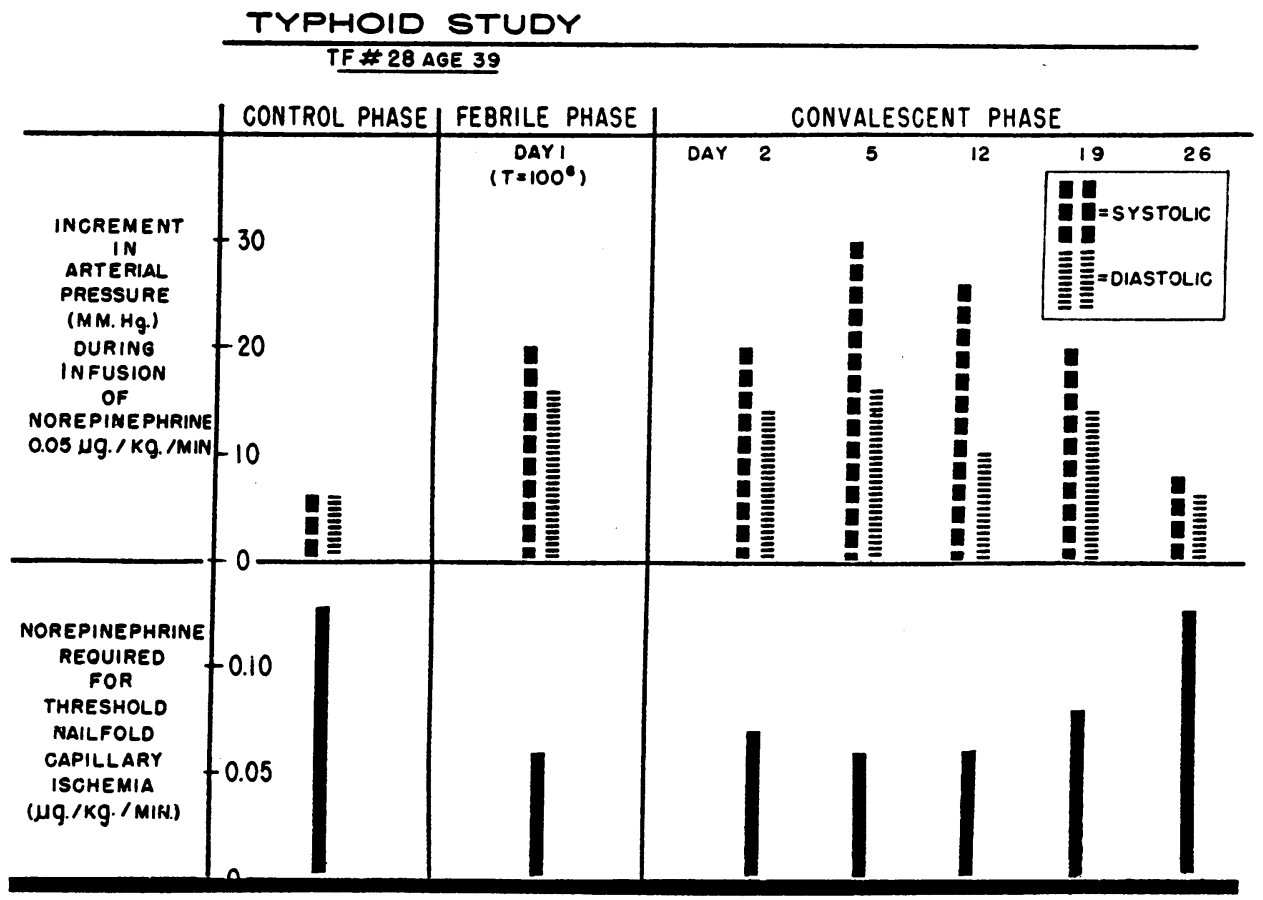

Fig. 1. VAscular ReActivity in TYPhoId Fever. Typical pattern of the altered reactivity of the arterial blood pressure and nailfold capillary bed to norepinephrine infusion during typhoid fever. The base-line arterial blood pressures during each assay were 118/70, 124/74, $114 / 70,116 / 68,126 / 80,110 / 64$, and $112 / 70$, respectively.

opposite arm was monitored by the auscultatory method. The mean arterial blood pressure was estimated by adding one-third the pulse pressure to the diastolic pressure. Blood flow through the nailfold capillary bed of the fourth finger of the extremity receiving the saline infusion was observed through a Leitz nailfold capillary microscope at seventyfold magnification. The nailfold skin was prepared by the application of a film of cedar oil. One-half hour later, or longer if the arterial blood pressure or nailfold capillary vasomotor activity had not stabilized, an infusion of $l$-norepinephrine in pyrogen-free physiologic saline ( $4 \mu \mathrm{g}$ per $\mathrm{ml}$ ) was substituted by turning a three-way stopcock without the knowledge of the subject. The rate of norepinephrine infusion was increased stepwise, and with each increment the maximal change in arterial blood pressure and pulse rates was recorded. Alterations in nailfold capillary vasomotor activity were observed concomitantly. The minimal rate of norepinephrine infusion required to induce ischemia of the capillary bed was determined by the point at which blood flow ceased through two or more capillary loops in the selected microscopic field. The technique and interpretation of this procedure for assay of capillary reactivity to catecholamines have been described in detail previously $(10,11)$. These assays were repeated at varying intervals during illness.

On the day after the above control studies, each sub- ject was given an intradermal injection of epinephrine ${ }^{2}$ or norepinephrine on the volar surface of the forearm or on the anterior abdominal wall. In all instances, $0.1-\mathrm{ml}$ volumes were injected through 27-gauge needles; unless otherwise specified, $100 \mu \mathrm{g}$ of the catecholamine base was administered. The resulting reactions were inspected at $15,30,60$, and 120 minutes and at 24 and 48 hours. The intradermal testing was repeated daily after the onset of illness. Daily measurements of circulating platelet levels were obtained before, during, and after typhoid illness employing a direct counting technique and ReesEcker solution (12); all platelet counts were performed by the same individual.

\section{Results}

Cardiovascular responses to catecholamines during typhoid fever. Control responses of systemic arterial blood pressure to norepinephrine infusions were obtained in nine subjects before their induced typhoid fever. Several days later, each subject was infected with viable $S$. typhosa given orally. The reactivity of the systemic arterial blood pressure to norepinephrine was reassayed

${ }^{2}$ Hydrochloride salt supplied by Winthrop Laboratories, New York. N. Y. 
TABLE I

Systemic vascular reactivity to l-norepinephrine during typhoid fever $(T F)$

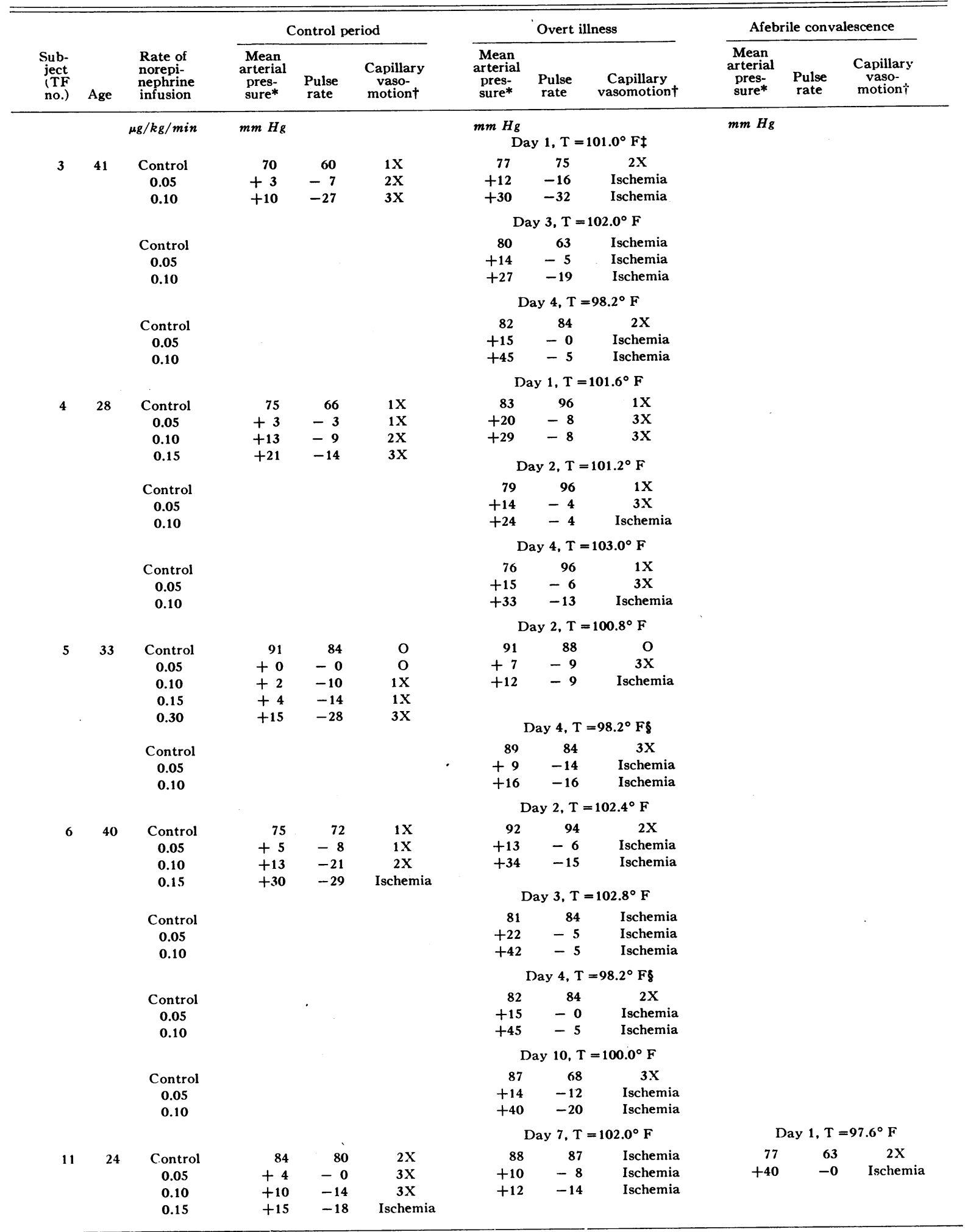


TABLE I-(Continued)

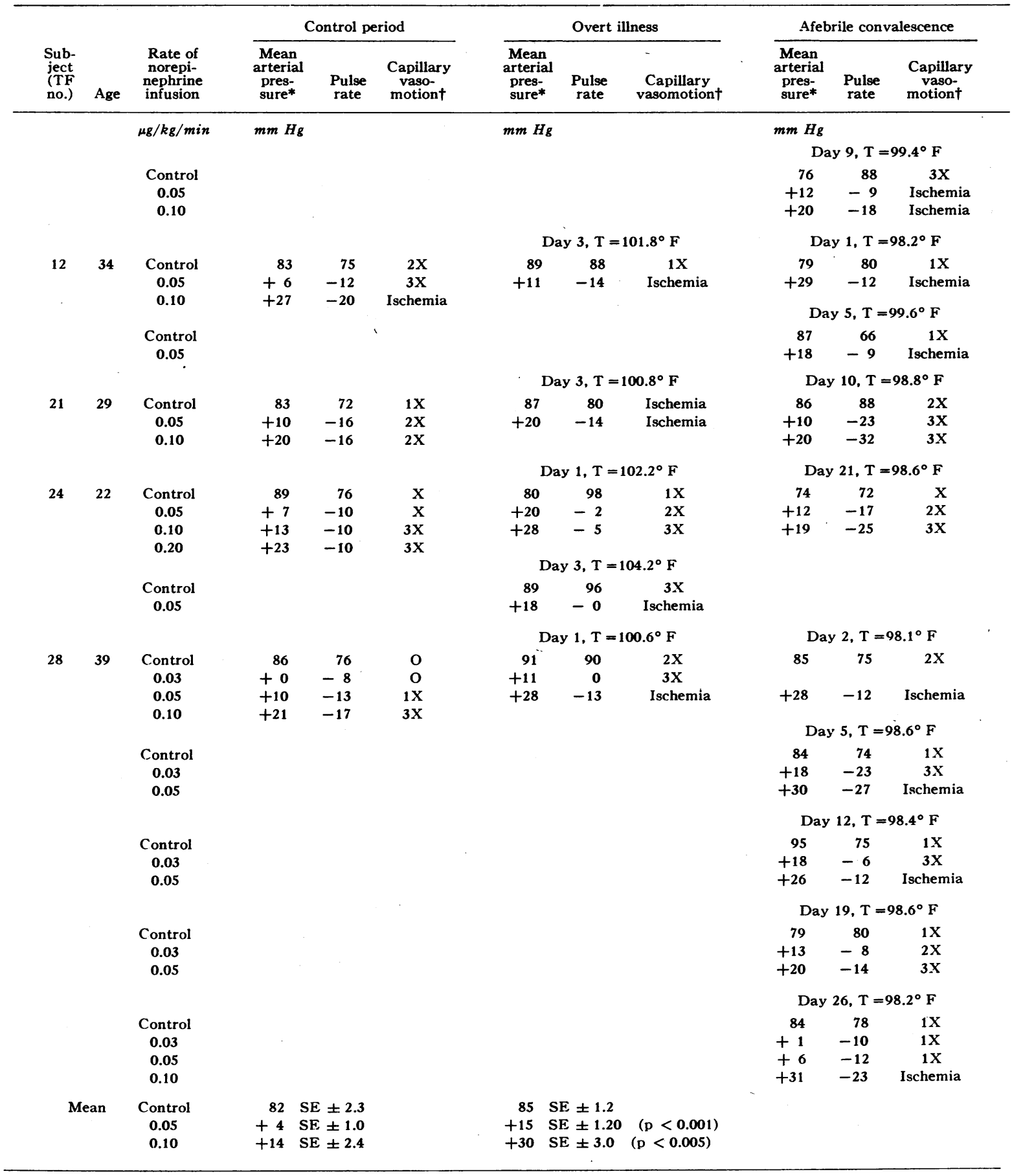

* Initial values represent absolute levels of mean arterial pressure; percentages of change from these levels during norepinephrine infusion are given below.

$\dagger$ Average number of constrictions of the arterial segments of the capillary loops of the nailfold per minute. $0=0-2, X=3-8,1 X=9-14$, $2 \mathrm{X}=15-25,3 \mathrm{X}=25-30$

$\ddagger T=$ temperature.

$\$ 60 \mathrm{mg}$ prednisone given orally 8 to 12 hours before testing. 
during overt typhoid illness and during subsequent convalescence at the same infusion rates employed for the control period. The responses are summarized in Table I, and a typical reaction pattern is detailed in Figure 1. Increased responsiveness of both diastolic and systolic arterial blood pressure to norepinephrine was observed consistently during illness and during the early phase of convalescence. The hyperreactivity in all subjects during illness, as judged by the percentage of increase in mean arterial blood pressure, was highly significant $(\mathrm{p}<0.001$ for norepinephrine infusion at rates of $0.05 \mu \mathrm{g}$ per $\mathrm{kg}$ per minute, and $\mathrm{p}<$ 0.005 for infusion at rates of $0.10 \mu \mathrm{g}$ per $\mathrm{kg}$ per minute). This hyperreactivity was not related to shifts in the base-line levels of arterial blood pressure, since no significant alterations in mean pressures were found during illness; the control values averaged $82 \mathrm{~mm} \mathrm{Hg}(\mathrm{SE} \pm 2.3)$ compared to 85 $\mathrm{mm} \mathrm{Hg}(\mathrm{SE} \pm 1.2)$ during illness. The hyperreactivity to catecholamines was also clinically apparent; the initial two subjects studied developed untoward reactions when tested during illness, whereas no symptoms occurred with twofold higher infusion rates during the control period.
In the first subject, severe substernal chest pain developed during infusion of $0.20 \mu \mathrm{g}$ per $\mathrm{kg}$ per minute of norepinephrine; the infusion was immediately discontinued, and the pain subsided rapidly. Subsequent electrocardiographic records failed to disclose any evidence of myocardial injury. The other subject, during the infusion of $0.15 \mu \mathrm{g}$ per $\mathrm{kg}$ per minute, complained of intense headache and vertigo, which subsided immediately after the infusion was discontinued. For these reasons, all subsequent testing during illness was limited to the lower dose ranges ( 0.05 and 0.10 $\mu \mathrm{g}$ per $\mathrm{kg}$ per minute) of norepinephrine.

The reactivity of the nailfold capillary bed to norepinephrine paralleled that of the arterial blood pressure. In every subject, the rate of norepinephrine infusion capable of obliterating visible capillary blood flow during illness was one-half or less that required during the control state. This hyperreactivity was highly significant $(p<0.005)$ and extended into the early convalescent phase. The vasomotor responses of the nailfold capillary bed are summarized in Table I, and a typical response pattern is shown in Figure 1. Although the base-line capillary vasomotor activity was fre-

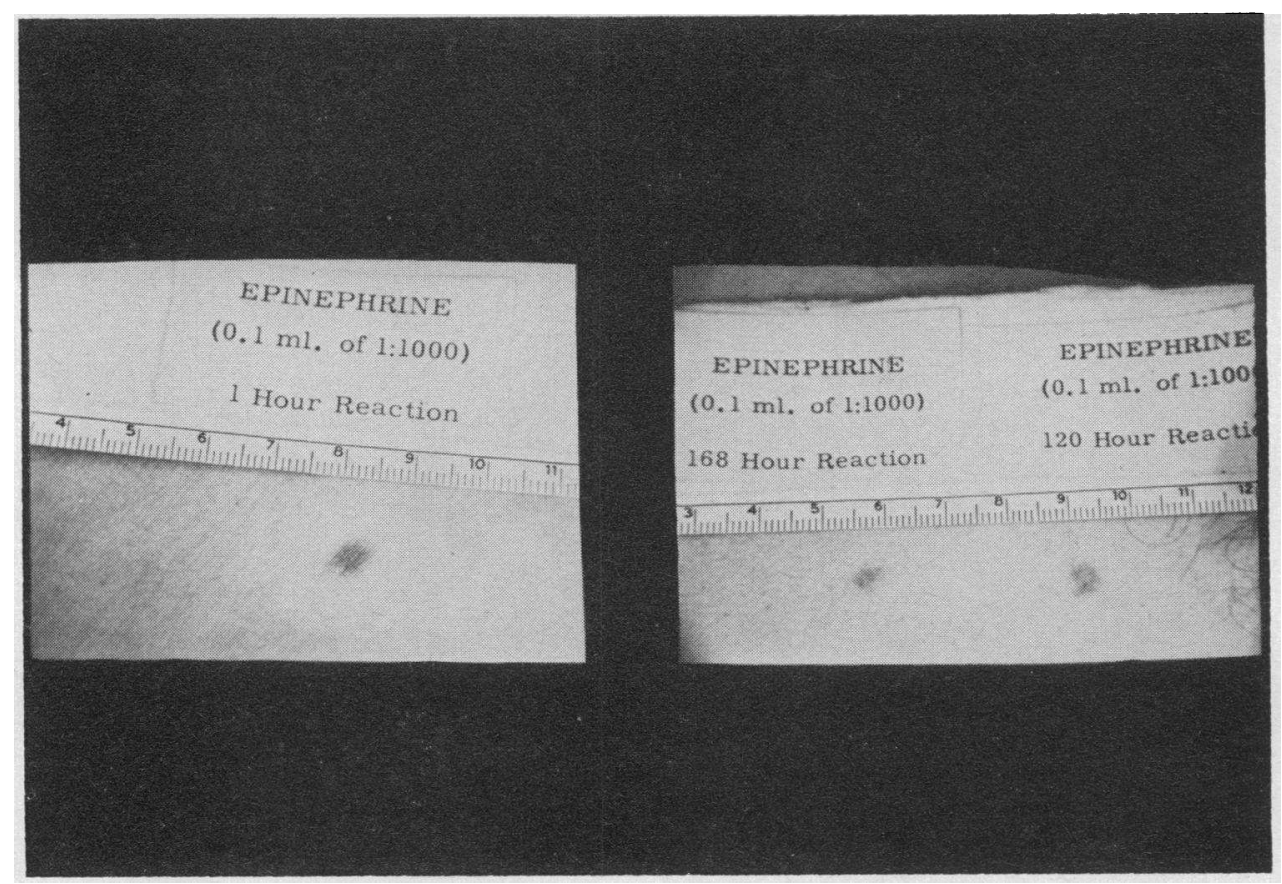

Fig. 2. VAscular Reactivity in typhoid fever. Typical gross appearance of the hemorrhagic reactions after intradermal injection of $0.1 \mathrm{ml}$ of $100 \mu \mathrm{g}$ of epinephrine during typhoid illness. 


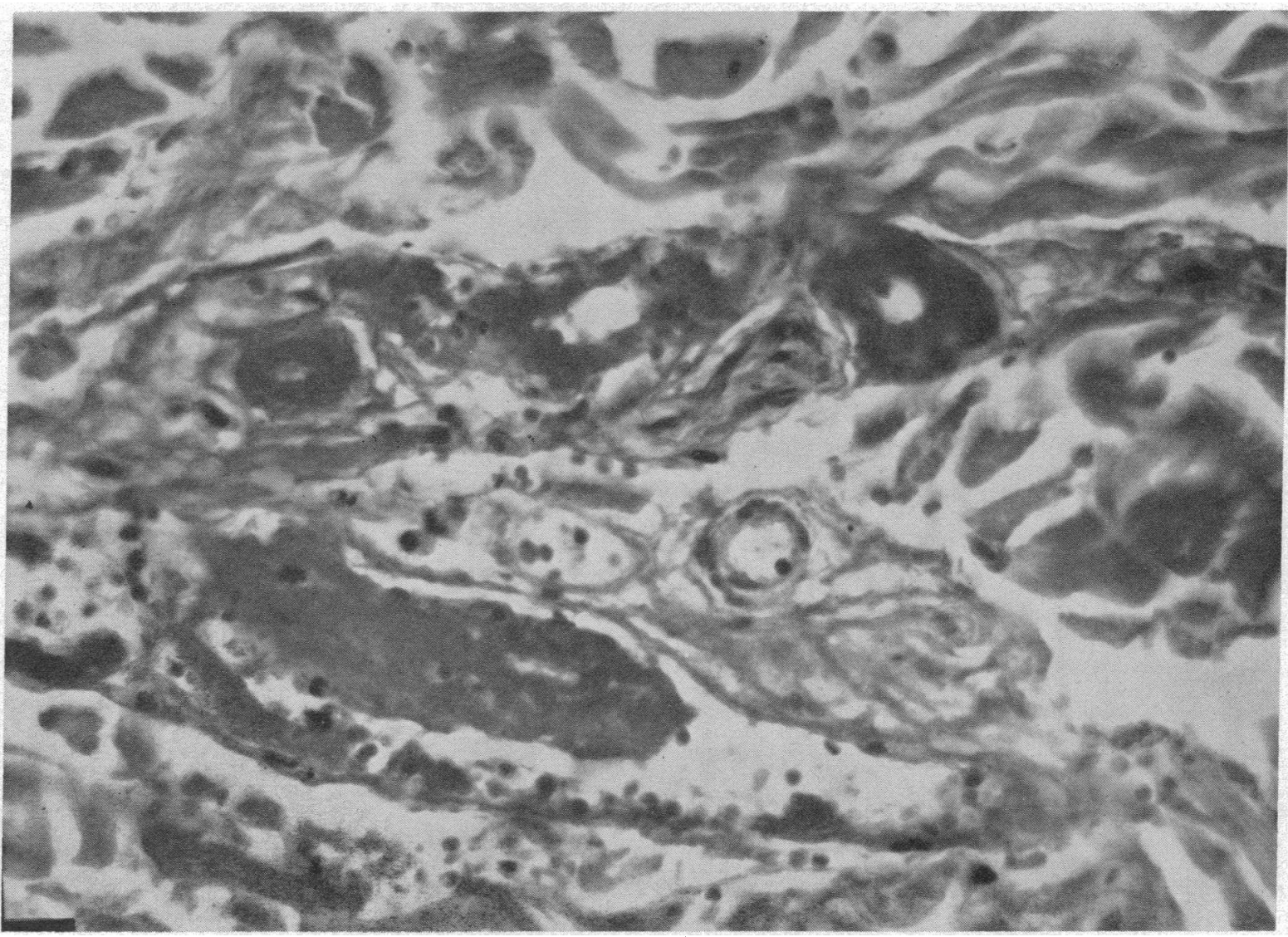

Fig. 3. VASCULAR REACTIVITY IN TYPHOID FEVER. Histologic appearance of a dermal hemorrhagic lesion 24 hours after injection of $0.1 \mathrm{ml}$ of $100 \mu \mathrm{g}$ of epinephrine during typhoid fever. The striking features are the extravasated red blood cells, the minimal inflammatory cellular reaction, and the fibrinoid arteriolar necrosis without thrombus formation $(\times 550)$.

quently intensified during typhoid fever (Table I), sufficient exceptions occurred to indicate that the hyperreactivity to norepinephrine during illness could not be attributed simply to such an intensified initial capillary vasomotion. In two subjects given prednisone on day 4 of overt typhoid illness (TF no. 5 and 6 ), transient defervescence and subsidence of toxemia ensued without detectable effects on the pressor or nailfold capillary hyperreactivity to norepinephrine (Table I).

The vascular effects after intradermal injections of $0.1 \mathrm{ml}$ of $100 \mu \mathrm{g}$ of epinephrine and norepinephrine during typhoid fever were also striking. During the control period, an initial intense central blanching developed surrounded by an irregular zone of erythema, both of which subsided gradually after several hours. During typhoid fever, local hemorrhagic reactions appeared in seven of nine subjects tested. The hemorrhagic reactions occurred with approximately comparable intensity in the skin of the anterior abdominal wall and volar surface of the forearm. In contrast to the hyperreactivity of the arterial blood pressure and nailfold capillary bed that was apparent on the initial day of overt illness, the dermal hemorrhagic reactions appeared 5 to 7 days after the onset of illness. The hemorrhagic lesions became grossly visible within 30 minutes after injection of the catecholamines and attained maximal size during the subsequent 3 to 4 hours. Only hemorrhagic lesions with diameters of $3 \mathrm{~mm}$ or greater were accepted as positive reactions. In no case could the hemorrhage be attributed to dermal trauma, since negative reactions consistently occurred with equal volumes of physiologic saline. Both epinephrine and norepinephrine were capable of 


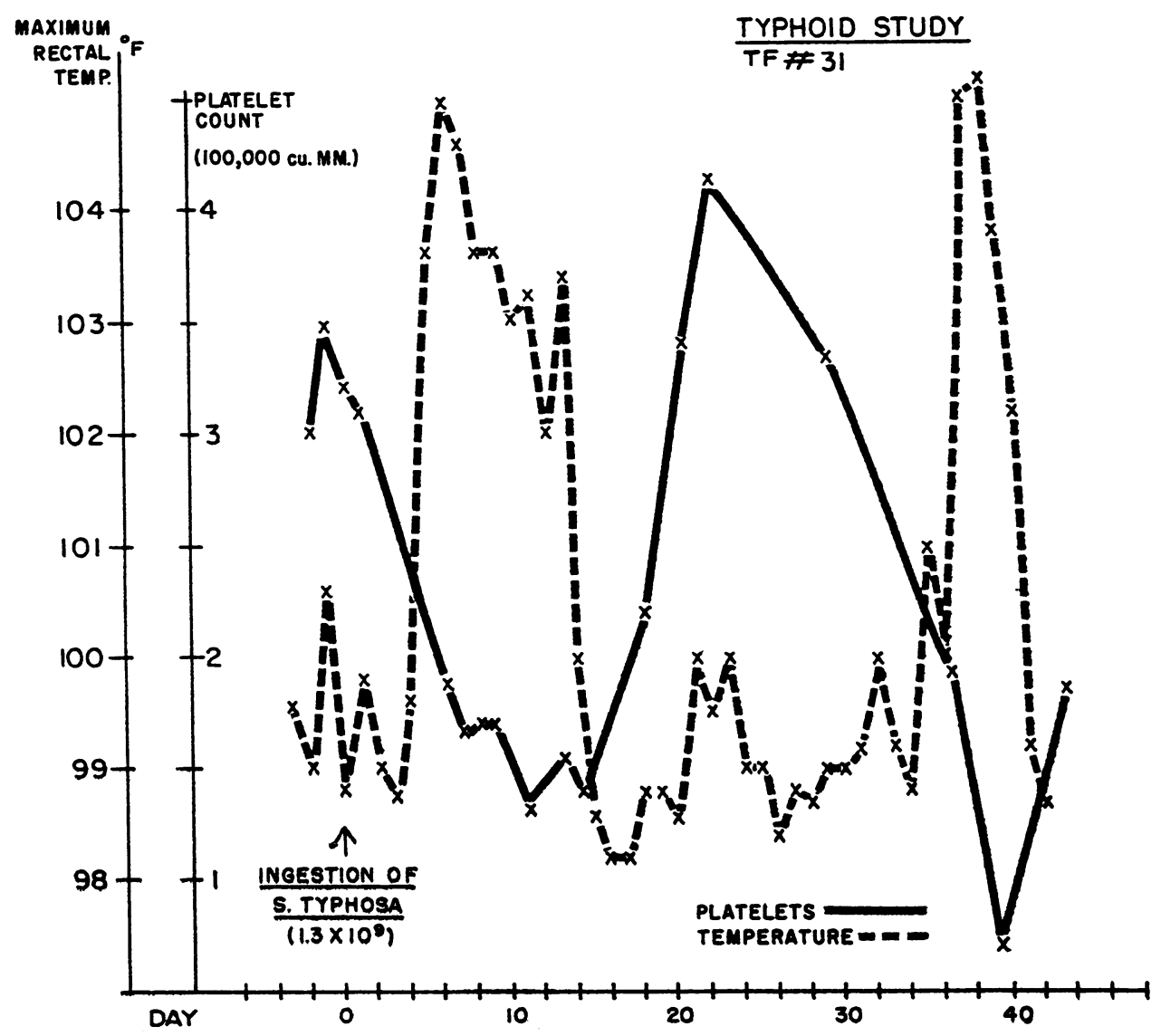

Fig. 4. Platelet levels in typhoid fever. Typical relation between the circulating platelet levels and the febrile course of typhoid fever. Note the prompt subsidence of the thrombocytopenia with defervescence and its recurrence during relapse.

inducing the hemorrhagic dermal lesions. In three subjects with positive reactions, graded dilutions of epinephrine were employed. In one subject, quantities down to but not below $10 \mu \mathrm{g}$ elicited positive gross lesions; in the other two, the threshold dose was $50 \mu \mathrm{g}$. The hemorrhagic dermal responses to the catecholamines continued into the initial week of the afebrile convalescent phase of typhoid fever, and one subject continued to respond for 3 weeks before reverting to normal (i.e., negative) reactivity.

A typical gross appearance of the dermal hemorrhagic lesions elicited by epinephrine during typhoid fever is shown in Figure 2. The histologic appearance, based upon biopsy of a hemorrhagic lesion 24 hours after the intradermal injection of $100 \mu \mathrm{g}$ of epinephrine, is shown in Figure 3. The major pathologic alterations were $a$ ) extravasated red blood cells, $b$ ) minimal inflammatory cellular response, and c) fibrinoid arteriolar necrosis without thrombus formation. Repeat biopsy from a comparable dermal area 24 hours after the same quantity of epinephrine in the same subject 4 weeks after convalescence from typhoid fever revealed no abnormal findings.

The altered cardiovascular responses after exposure to endotoxin may result from the release of vasoactive endogenous substances such as serotonin $(13,14)$. Since platelets are readily clumped by endotoxin and then release serotonin (15), the effect of typhoidal infection on the circulating platelets was determined. In each of six subjects, a precipitous decline in circulating platelet levels consistently developed concomitantly with the rise in temperature during overt illness. The thrombocytopenia persisted throughout the 
febrile phase, returned to normal when illness abated after institution of antibiotic treatment, and again fell if relapse occurred. Figure 4 illustrates this relationship. Conceivably, therefore, the enhanced cardiovascular responses to catecholamines were initiated by platelet injury, but further studies are required to support this relationship. Certainly, a maintained thrombocytopenia is not required for the hyperreactivity; despite the consistent return of platelets to normal levels when fever abated, cardiovascular hyperreactivity to the catecholamines persisted for days to weeks longer. The hyperreactivity could not be attributed to an inability to detoxify catechola-

TABLE II

Systemic vascular reactivity to l-norepinephrine during tularemia (TU)

\begin{tabular}{|c|c|c|c|c|c|c|c|c|}
\hline \multirow[b]{2}{*}{$\begin{array}{l}\text { Sub- } \\
\text { ject } \\
\text { (TU } \\
\text { no.) }\end{array}$} & \multirow[b]{2}{*}{ Age } & \multirow[b]{2}{*}{$\begin{array}{c}\text { Rate of } \\
\text { norepi- } \\
\text { nephrine } \\
\text { infusion }\end{array}$} & \multicolumn{3}{|c|}{ Control period } & \multicolumn{3}{|c|}{ Illness } \\
\hline & & & $\begin{array}{c}\text { Mean } \\
\text { arterial } \\
\text { pressure* }\end{array}$ & $\begin{array}{l}\text { Pulse } \\
\text { rate }\end{array}$ & $\begin{array}{c}\text { Capillary } \\
\text { vasomotion } \dagger\end{array}$ & $\begin{array}{c}\text { Mean } \\
\text { arterial } \\
\text { pressure* }\end{array}$ & $\begin{array}{l}\text { Pulse } \\
\text { rate }\end{array}$ & $\begin{array}{c}\text { Capillary } \\
\text { vasomotion } \dagger\end{array}$ \\
\hline & & $\mu g / k g / m i n$ & $m m \mathrm{Hg}$ & & & $m m \mathrm{Hg}$ & & \\
\hline & & & & & & $\mathrm{Da}$ & $3, T=$ & $.6^{\circ} \mathrm{F}$ \\
\hline \multirow[t]{2}{*}{15} & 33 & $\begin{array}{c}\text { Control } \\
0.05 \\
0.10\end{array}$ & $\begin{array}{r}107 \\
+21 \\
+32\end{array}$ & $\begin{array}{r}75 \\
-20 \\
-25\end{array}$ & $\begin{array}{r}\mathrm{O} \\
2 \mathrm{X}\end{array}$ & $\begin{array}{r}100 \\
+11 \\
+16\end{array}$ & $\begin{array}{r}80 \\
-\quad 3 \\
-10\end{array}$ & $\begin{array}{r}\mathrm{O} \\
\mathrm{O} \\
1 \mathrm{X}\end{array}$ \\
\hline & & & & & & \multicolumn{3}{|c|}{ Day $3, \mathrm{~T}=100.8^{\circ} \mathrm{F}$} \\
\hline \multirow[t]{2}{*}{16} & 29 & $\begin{array}{l}\text { Control } \\
0.05 \\
0.10\end{array}$ & $\begin{array}{r}77 \\
+20 \\
+30\end{array}$ & $\begin{array}{r}82 \\
-\quad 2 \\
-12\end{array}$ & $\begin{array}{l}2 \mathrm{X} \\
3 \mathrm{X} \\
3 \mathrm{X}\end{array}$ & $\begin{array}{r}78 \\
+11 \\
+14\end{array}$ & $\begin{array}{r}78 \\
-5 \\
-11\end{array}$ & $\begin{array}{l}2 \mathrm{X} \\
3 \mathrm{X} \\
3 \mathrm{X}\end{array}$ \\
\hline & & & & & & \multicolumn{3}{|c|}{ Day $3, T=100.6^{\circ} \mathrm{F}$} \\
\hline \multirow[t]{2}{*}{18} & 26 & $\begin{array}{c}\text { Control } \\
0.05 \\
0.10\end{array}$ & $\begin{array}{r}75 \\
+27 \\
+36\end{array}$ & $\begin{array}{r}66 \\
-\quad 0 \\
-0\end{array}$ & $\begin{array}{l}2 \mathrm{X} \\
3 \mathrm{X} \\
3 \mathrm{X}\end{array}$ & $\begin{array}{r}77 \\
+14 \\
+26\end{array}$ & $\begin{array}{r}72 \\
-8 \\
-17\end{array}$ & $\begin{array}{l}1 \mathrm{X} \\
1 \mathrm{X} \\
1 \mathrm{X}\end{array}$ \\
\hline & & & & & & \multicolumn{3}{|c|}{ Day $2, \mathrm{~T}=100.6^{\circ} \mathrm{F}$} \\
\hline \multirow[t]{2}{*}{19} & 37 & $\begin{array}{c}\text { Control } \\
0.05 \\
0.10\end{array}$ & $\begin{array}{r}72 \\
+24 \\
+32\end{array}$ & $\begin{array}{r}68 \\
-23 \\
-28\end{array}$ & $\begin{array}{c}2 \mathrm{X} \\
\text { Ischemia } \\
\text { Ischemia }\end{array}$ & $\begin{array}{r}80 \\
+20 \\
+26\end{array}$ & $\begin{array}{r}72 \\
-13 \\
-21\end{array}$ & $\begin{array}{c}2 \mathrm{X} \\
\text { Ischemia } \\
\text { Ischemia }\end{array}$ \\
\hline & & & & & & \multicolumn{3}{|c|}{ Day $2, T=101.8^{\circ} \mathrm{F}$} \\
\hline \multirow[t]{2}{*}{20} & 27 & $\begin{array}{c}\text { Control } \\
0.05 \\
0.10\end{array}$ & $\begin{array}{r}77 \\
+9 \\
+22\end{array}$ & $\begin{array}{r}57 \\
-5 \\
-5\end{array}$ & $\begin{array}{c}\text { 1X } \\
\text { 1X } \\
\text { lschemia }\end{array}$ & $\begin{array}{r}85 \\
+5 \\
+12\end{array}$ & $\begin{array}{r}84 \\
-14 \\
-25\end{array}$ & $\begin{array}{c}1 \mathrm{X} \\
1 \mathrm{X} \\
\text { Ischemia }\end{array}$ \\
\hline & & & & & & \multicolumn{3}{|c|}{ Day $2, \mathrm{~T}=102.4^{\circ} \mathrm{F}$} \\
\hline \multirow[t]{2}{*}{75} & 44 & $\begin{array}{c}\text { Control } \\
0.05 \\
0.10\end{array}$ & $\begin{array}{r}82 \\
+\quad 6 \\
+10\end{array}$ & $\begin{array}{r}87 \\
-10 \\
-14\end{array}$ & $\begin{array}{l}1 \mathrm{X} \\
1 \mathrm{X} \\
1 \mathrm{X}\end{array}$ & $\begin{array}{r}86 \\
+6 \\
+8\end{array}$ & $\begin{array}{r}78 \\
-8 \\
-8\end{array}$ & $\begin{array}{l}1 \mathrm{X} \\
1 \mathrm{X} \\
1 \mathrm{X}\end{array}$ \\
\hline & & & & & & \multicolumn{3}{|c|}{ Day $2, T=104.0^{\circ} \mathrm{F}$} \\
\hline \multirow[t]{2}{*}{76} & 42 & $\begin{array}{c}\text { Control } \\
0.05 \\
0.10\end{array}$ & $\begin{array}{r}80 \\
+22 \\
+36\end{array}$ & $\begin{array}{r}60 \\
-\quad 7 \\
-15\end{array}$ & $\begin{array}{c}\mathrm{O} \\
\text { Ischemia }\end{array}$ & $\begin{array}{r}73 \\
+11 \\
+21\end{array}$ & $\begin{array}{r}83 \\
-0 \\
-14\end{array}$ & $\begin{array}{r}\mathrm{O} \\
\mathrm{O} \\
2 \mathrm{X}\end{array}$ \\
\hline & & & & & & \multicolumn{3}{|c|}{ Day $2, \mathrm{~T}=105.6^{\circ} \mathrm{F}$} \\
\hline \multirow[t]{2}{*}{77} & 25 & $\begin{array}{c}\text { Control } \\
0.05 \\
0.10\end{array}$ & $\begin{array}{r}86 \\
+12 \\
+28\end{array}$ & $\begin{array}{r}66 \\
-23 \\
-30\end{array}$ & $\begin{array}{c}\text { 1X } \\
\text { 1X } \\
\text { Ischemia }\end{array}$ & $\begin{array}{r}73 \\
+5 \\
+14\end{array}$ & $\begin{array}{r}92 \\
-2 \\
-6\end{array}$ & $\begin{array}{l}3 \mathrm{X} \\
3 \mathrm{X} \\
3 \mathrm{X}\end{array}$ \\
\hline & & & & & & \multicolumn{3}{|c|}{ Day $2, T=104.4^{\circ} \mathrm{F}$} \\
\hline \multirow[t]{2}{*}{78} & 37 & $\begin{array}{c}\text { Control } \\
0.05 \\
0.10\end{array}$ & $\begin{array}{r}81 \\
+\quad 7 \\
+25\end{array}$ & $\begin{array}{r}72 \\
-8 \\
-22\end{array}$ & $\begin{array}{l}1 \mathrm{X} \\
2 \mathrm{X} \\
2 \mathrm{X}\end{array}$ & $\begin{array}{r}89 \\
+\quad 5 \\
+25\end{array}$ & $\begin{array}{r}105 \\
-\quad 7 \\
-17\end{array}$ & $\begin{array}{l}1 \mathrm{X} \\
2 \mathrm{X} \\
2 \mathrm{X}\end{array}$ \\
\hline & Mean & $\begin{array}{c}\text { Control } \\
0.05 \\
0.10\end{array}$ & \multicolumn{3}{|c|}{$\begin{array}{r}82 \mathrm{SE} \pm 3.5 \\
+16 \mathrm{SE} \pm 2.7 \\
+28 \mathrm{SE} \pm 2.7\end{array}$} & \multicolumn{2}{|c|}{$\begin{array}{r}82 \mathrm{SE} \pm 2.9 \\
+10 \mathrm{SE} \pm 1.7 \\
+18 \mathrm{SE} \pm 2.2\end{array}$} & $\begin{array}{l}<0.10) \\
<0.025)\end{array}$ \\
\hline
\end{tabular}

*, † See footnotes to Table I. 
TABLE III

Systemic vascular reactivity to l-norepinephrine during sandfly fever $(S F)$

\begin{tabular}{|c|c|c|c|c|c|c|c|c|}
\hline \multirow[b]{2}{*}{$\begin{array}{l}\text { Subject } \\
\text { (SF no.) }\end{array}$} & \multirow[b]{2}{*}{ Age } & \multirow{2}{*}{$\begin{array}{l}\text { Rate of } \\
\text { norepi- } \\
\text { nephrine } \\
\text { infusion }\end{array}$} & \multicolumn{3}{|c|}{ Control period } & \multicolumn{3}{|c|}{ Illness } \\
\hline & & & $\underset{\substack{\text { Mean } \\
\text { arterial } \\
\text { pressure* }}}{ }$ & $\begin{array}{l}\text { Pulse } \\
\text { rate }\end{array}$ & $\begin{array}{c}\text { Capillary } \\
\text { vasomotion }\end{array}$ & $\underset{\substack{\text { Mean } \\
\text { arterial } \\
\text { pressure* }}}{ }$ & $\begin{array}{l}\text { Pulse } \\
\text { rate }\end{array}$ & $\begin{array}{c}\text { Capillary } \\
\text { vasomotion } \dagger\end{array}$ \\
\hline & & $\mu g / \mathrm{kg} / \mathrm{min}$ & $m m \mathrm{Hg}$ & & & \multicolumn{3}{|c|}{$m m \mathrm{Hg}$} \\
\hline \multirow[t]{2}{*}{1} & 25 & $\begin{array}{l}\text { Control } \\
0.05 \\
0.10 \\
0.15\end{array}$ & $\begin{array}{r}93 \\
+\quad 0 \\
+7 \\
+11\end{array}$ & $\begin{array}{r}60 \\
-\quad 0 \\
-0 \\
-0\end{array}$ & $\begin{array}{l}1 \mathrm{X} \\
1 \mathrm{X} \\
2 \mathrm{X} \\
3 \mathrm{X}\end{array}$ & $\begin{array}{r}98 \\
+\quad 0 \\
+2 \\
+6\end{array}$ & $\begin{array}{r}92 \\
-\quad 0 \\
-0 \\
-0\end{array}$ & $\begin{array}{l}1 \mathrm{X} \\
1 \mathrm{X} \\
1 \mathrm{X} \\
2 \mathrm{X}\end{array}$ \\
\hline & & & & & & \multicolumn{3}{|c|}{$\operatorname{Day} 1, \mathrm{~T}=102^{\circ} \mathrm{F}$} \\
\hline \multirow[t]{2}{*}{2} & 39 & $\begin{array}{c}\text { Control } \\
0.05 \\
0.10 \\
0.15\end{array}$ & $\begin{array}{r}82 \\
+\quad 1 \\
+6 \\
+12\end{array}$ & $\begin{array}{r}66 \\
-12 \\
-21 \\
-24\end{array}$ & $\begin{array}{l}1 \mathrm{X} \\
1 \mathrm{X} \\
2 \mathrm{X} \\
2 \mathrm{X}\end{array}$ & $\begin{array}{r}82 \\
+\quad 0 \\
+2 \\
+4\end{array}$ & $\begin{array}{r}88 \\
-9 \\
-9 \\
-14\end{array}$ & $\begin{array}{l}1 \mathrm{X} \\
1 \mathrm{X} \\
2 \mathrm{X} \\
2 \mathrm{X}\end{array}$ \\
\hline & & & & & & \multicolumn{3}{|c|}{ Day $1, T=103.2^{\circ} \mathrm{F}$} \\
\hline \multirow[t]{2}{*}{3} & 36 & $\begin{array}{c}\text { Control } \\
0.05 \\
0.10 \\
0.15\end{array}$ & $\begin{array}{r}94 \\
+2 \\
+5 \\
+11\end{array}$ & $\begin{array}{r}60 \\
-5 \\
-13 \\
-13\end{array}$ & $\begin{array}{l}2 \mathrm{X} \\
2 \mathrm{X} \\
2 \mathrm{X} \\
2 \mathrm{X}\end{array}$ & $\begin{array}{r}97 \\
+0 \\
+1 \\
+4\end{array}$ & $\begin{array}{r}100 \\
-\quad 1 \\
-\quad 2 \\
-4\end{array}$ & $\begin{array}{l}2 \mathrm{X} \\
2 \mathrm{X} \\
2 \mathrm{X} \\
2 \mathrm{X}\end{array}$ \\
\hline & Mean & $\begin{array}{c}\text { Control } \\
0.05 \\
0.10 \\
0.15\end{array}$ & $\begin{array}{r}90 \\
+\quad 1 \\
+6 \\
+11\end{array}$ & & & \multicolumn{3}{|c|}{$\left.\begin{array}{r}92 \\
+\quad 0 \\
+\quad 2 \\
+\quad 5\end{array}\right\}(p<0.05)$} \\
\hline
\end{tabular}

$*$, $\uparrow$ See footnotes to Table I.

mines, since serial daily studies of urinary catecholamine excretion, as well as one major degradation product, 3-methoxy-4-hydroxymandelic acid, failed to show any increase above the control base-line values in two subjects with typical typhoid fever. ${ }^{3}$ The antibiotic (chloramphenicol) employed for therapy of typhoid fever could not account for the cardiovascular hyperreactivity, since this was already apparent before therapy was initiated.

Two subjects who failed to develop overt typhoid illness after ingestion of viable typhoid bacilli were retested with catecholamines at a time corresponding to that when other subjects exhibited illness. No alteration in cardiovascular reactivity to the catecholamines was observed.

Systemic cardiovascular responses to catecholamines during tularemia and sandfly fever. In contrast to typhoid fever, hyperreactivity to the catecholamines was not observed in volunteers during the course of tularemia or sandfly fever

3 Serial studies performed by Dr. John Wiswell, University of Maryland School of Medicine, employing previously described assay procedures $(16,17)$.
(Tables II and III). Actually, during the febrile phase of these illnesses, a significant diminution in reactivity occurred based on the percentage of change in mean arterial blood pressure during norepinephrine infusions. In tularemic patients, the significance of the impaired pressor response to $0.10 \mu \mathrm{g}$ per $\mathrm{kg}$ per minute of norepinephrine was $\mathrm{p}<0.025$; in the sandfly fever subjects, $\mathrm{p}<0.05$ for the combined impairment of responses to 0.05 , 0.10 , and $0.15 \mu \mathrm{g}$ per $\mathrm{kg}$ per minute of norepinephrine. These reduced pressor responses were not attributable to shifts in the base-line mean arterial blood pressure, since no significant changes occurred during illness (Tables II and III). Although some subjects exhibited diminution in nailfold capillary vasomotor responses to norepinephrine, no over-all significant changes in reactivity of this bed were observed. All subjects were also skin tested serially with $0.1 \mathrm{ml}$ of $100 \mu \mathrm{g}$ of epinephrine and norepinephrine during the febrile and convalescent phases of illness. In no case were hemorrhagic reactions observed.

Effect of bacterial endotoxin on cardiovascular responses to catecholamines in man. The reac- 

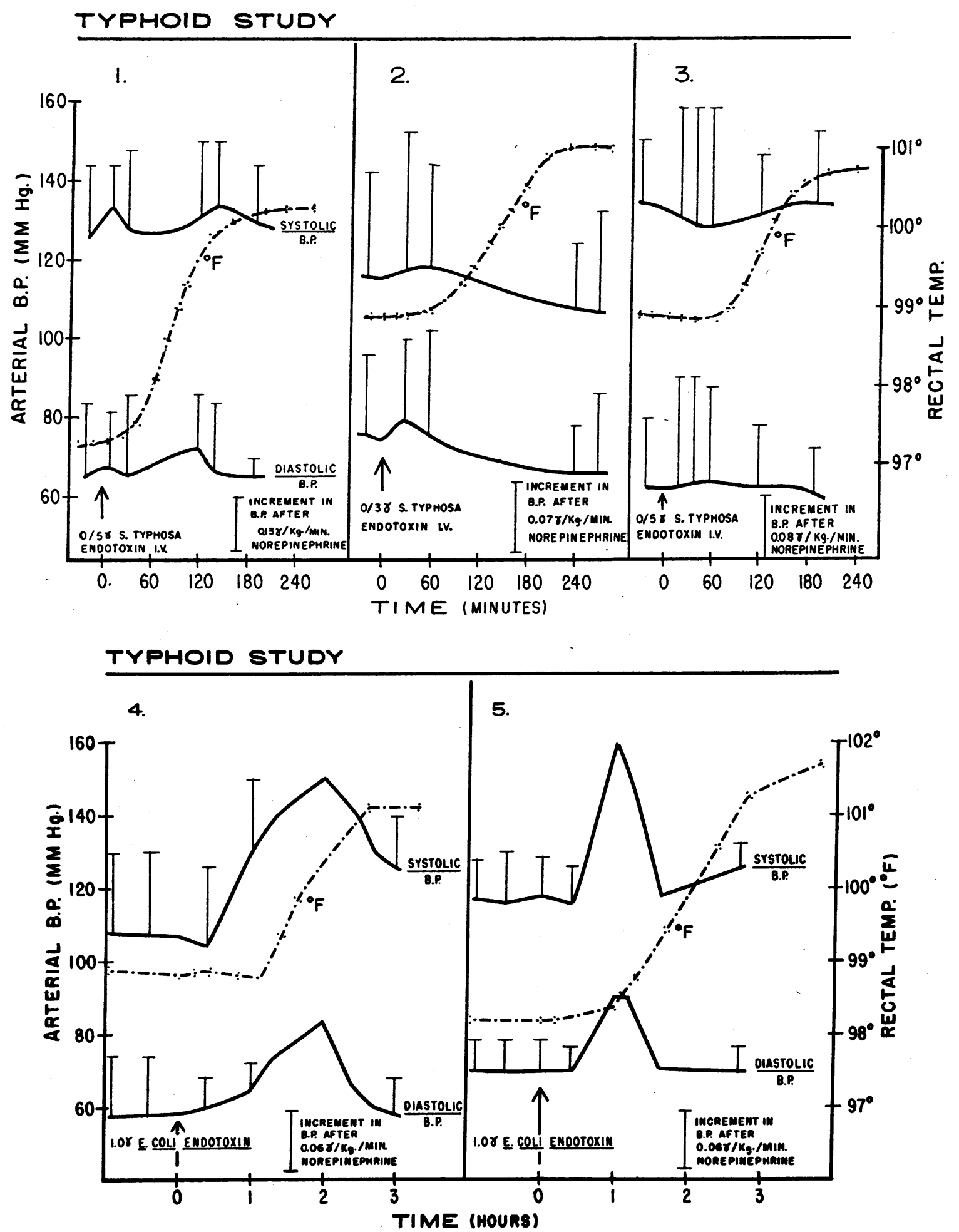

Fig. 5. VAscular Reactivity to endotoxin. The effects of single iv injections of purified bacterial endotoxins on the arterial blood pressure and its reactivity to infusion of norepinephrine in five normal subjects. The increases in rectal temperatures are depicted by the broken lines. 
tivity of the arterial blood pressure and of the nailfold capillary bed to norepinephrine was studied in five normal volunteers before and after single iv injections of a quantity of purified bacterial endotoxin sufficient to evoke moderate febrile and toxic responses. The $S$. typhosa endotoxin ${ }^{4}(0.5 \mu \mathrm{g}$ per $\mathrm{ml})$ was suspended in pyrogenfree physiologic saline, and the Escherichia coli endotoxin $(0127 \mathrm{~B} 8)^{5}$ was suspended in a concentration of $1 \mu \mathrm{g}$ per ml. Both preparations were bacteriologically sterile, and their ability to evoke febrile and toxic reactions in larger numbers of volunteers has been documented previously (2).

During the base-line observations, an infusion of pyrogen-free physiologic saline was begun in the antecubital vein of one arm while arterial blood pressure was monitored by the auscultatory method in the opposite extremity. Intermittently, without the knowledge of the subject, a constant infusion of norepinephrine was substituted by turning a three-way stopcock. The arterial blood pressure and nailfold capillary responses were monitored until the responses became constant. The norepinephrine was then discontinued and the saline infusion reinstituted. These tests were repeated at various intervals after the iv injection of endotoxin. The responses of the arterial blood pressure to endotoxin and the increments in pressure evoked by norepinephrine during the initial 3 to 4 hours after endotoxin are shown in Figure 5. No significant or consistent hyperreactivity to norepinephrine was observed; indeed, diminution in reactivity occurred during the maximal febrile phase. Moreover, no changes in nailfold capillary vasomotor reactivity could be detected. All subjects experienced moderate toxic reactions from the endotoxin, i.e., headache, chilliness, myalgia, and anorexia.

Fifteen additional subjects were tested by intradermal injections of $0.1 \mathrm{ml}$ of $100 \mu \mathrm{g}$ of epinephrine or norepinephrine at 0,2 , and 8 hours after the iv administration of $0.5 \mu \mathrm{g} S$. typhosa endotoxin. No hemorrhagic lesions were observed. In contrast, gross hemorrhagic lesions developed consistently in 10 albino rabbits (weight, 1.0 to $1.3 \mathrm{~kg}$ ) when the epinephrine was injected

\footnotetext{
4 A highly purified material (18) kindly supplied by Dr. Maurice Landy, National Institutes of Health.

5 A Boivin type preparation (19) supplied by Difco Laboratories, Detroit, Mich.
}

intradermally into the anterior abdominal wall 2 hours after iv injections of $0.5 \mu \mathrm{g}$ of the endotoxin. $^{6}$

The effect of mixtures of epinephrine and endotoxin were assayed in six additional normal subjects. The skin of the anterior abdominal wall received injections as follows: all subjects received $0.25 \mathrm{ml}$ containing $5 \mu \mathrm{g}$ of $S$. typhosa endotoxin and $50 \mu \mathrm{g}$ of epinephrine in the right upper quadrant, endotoxin in physiologic saline in the left upper quadrant, and epinephrine in physiologic saline in the right lower quadrant. The endotoxin and epinephrine, when employed singly for the control injections, were constituted to the same concentrations as in the mixtures. All reactions were carefully inspected at 4 and 24 hours and daily thereafter for 7 days. No gross hemorrhagic lesions were produced by the endotoxinepinephrine mixtures in man, in contrast to those consistently evoked in the anterior abdominal wall of young albino rabbits with concentrations of endotoxin down to (but not below) one-fifth those employed here. Indeed, except for the initial blanching, the gross appearances of the endotoxin-epinephrine mixtures in man simulated those produced by the endotoxin-saline mixtures. Each was characterized by an intense inflammatory reaction persisting for approximately 2 weeks. Of interest, all subjects complained of severe "beesting" sensations for 24 to 48 hours at the site of the epinephrine-endotoxin mixture injection; no discomfort was noted at the control sites.

\section{Discussion}

The similarities between the clinical and pathological manifestations of typhoid fever and the reactions induced by bacterial endotoxin suggest that the latter may play an important role in the pathogenesis of this infectious illness (20). Supporting this hypothesis, our previous study (2) showed that significant tolerance is acquired to the pyrogenic activity of homologous and heterologous bacterial endotoxins after typhoid fever. In the present investigation, cardiovascular reactivity to catecholamines was selected for study because increased reactivity characteristically fol-

${ }^{6}$ The iv injection of less than $0.1 \mu \mathrm{g}$ of this $S$. typhosa endotoxin failed to consistently prepare rabbits for the dermal hemorrhagic reactions to epinephrine. 
lows the injection of endotoxin into the intact rabbit and rat (4-7). Moreover, intradermal testing with catecholamines during a variety of illnesses in man supports the concept that hemorrhagic responses may accompany endotoxemia (21). Significant increases in cardiovascular reactivity to norepinephrine developed during typhoid fever as judged by the percentage of rise in mean arterial blood pressure. Since cardiac output and total peripheral resistance were not measured, the relative contributions of each parameter to the enhanced pressor response could not be quantitated. Nevertheless, enhanced peripheral vascular reactivity appeared to participate in the exaggerated pressor response, as indicated by the increases in vasomotor activity of the nailfold capillary bed during norepinephrine infusion. In addition, gross hemorrhagic lesions developed at the sites of intradermal injection of both epinephrine and norepinephrine. Histologically, such catecholamine-induced dermal lesions were similar to those described in rabbits pretreated with endotoxin (4). These hyperreactive cardiovascular responses could not be attributed to nonspecific effects of fever or infection; significant depression of reactivity to catecholamines rather than enhancement was observed during the febrile phases of tularemia and sandfly fever. The hyperreactivity also could not be attributed to shifts in base-line arterial blood pressure. That it reflected an inability to detoxify catecholamines is unlikely, since no increases in 24-hour urinary excretion of catecholamines or their degradation products were detected in two subjects studied throughout illness. Nor could the hyperreactivity be attributed to the chloramphenicol employed therapeutically as enhanced responsiveness was apparent before its administration. Conceivably, release of vasoactive substances from injured platelets contributed to the hyperreactivity, since endotoxin causes platelet clumping and release of serotonin (15), a substance postulated to induce vascular hyperreactivity to catecholamines $(13,14)$. Moreover, human platelets are rich in serotonin (22), and thrombocytopenia promptly appeared at the onset of overt illness and was maintained throughout the febrile phase. Further studies, however, are required to define the role of platelet injury during typhoid fever.

Although the above findings suggested that en- dotoxin might be responsible for the augmented cardiovascular reactivity to catecholamines during typhoid illness, subsequent observations required reconciliation with this interpretation. a) The administration of single iv doses of endotoxin to normal subjects sufficient to evoke febrile and toxic reactions as severe as those seen during the early phase of typhoid illness failed to induce vascular hyperreactivity to catecholamines. This finding, however, does not exclude the role of endotoxin. The physiologic derangements induced by a single iv injection of endotoxin into a normal subject may not reflect those evoked by endotoxemia during infection. Indeed, significant hyperreactivity to the pyrogenic and toxic effects of endotoxin is known to occur during typhoid fever $(23,24)$. b) Intradermal injection of mixtures of endotoxin with epinephrine in normal subjects did not elicit local hemorrhagic lesions, and $c$ ) the cardiovascular hyperreactivity to catecholamines persisted 1 or more weeks into the afebrile convalescent phase of typhoid fever. These observations are compatible with the hypothesis that endotoxin induces vascular hyperreactivity to catecholamines by indirect action and that the responsible intermediates can remain active for some time after endotoxemia $(4,13)$. d) Cardiovascular hyperreactivity to catecholamines failed to appear during tularemia, a disease clinically similar to typhoid fever, induced by a gram-negative bacteria containing endotoxin, and resulting in endotoxin tolerance (2). Insufficient release of physiologically active endotoxin may occur during tularemic infection to induce cardiovascular hyperreactivity. Moreover, the tularemic infection was generally interrupted with streptomycin after only 36 hours of overt illness; vascular hyperreactivity to catecholamines at a later phase in untreated disease cannot be excluded.

Although the findings thus remain compatible with the hypothesis that endotoxin initiates the vascular hyperreactivity to catecholamines during typhoid fever in man, we emphasize that this relationship is unproven and that other mechanisms may be operative. Thus the intestinal mucosa of man and animals possesses high serotonin concentrations $(25,26)$. Intestinal injury by ischemia confers catecholamine sensitizing properties to the portal blood of rabbits, presumably by augmenting the release of serotonin from the 
bowel (14). Conceivably, intestinal inflammation during typhoid fever in man evokes similar enhanced release of such vasoactive substances.

\section{Summary}

Cardiovascular reactivity to catecholamines was studied in previously healthy volunteers before and during induced typhoid fever, tularemia, and sandfly fever. During typhoid fever, significant increases in reactivity developed as evidenced by the increments in mean arterial blood pressure and nailfold capillary vasomotor activity during norepinephrine infusions, and by the appearance of gross hemorrhagic lesions after intradermal injection of epinephrine or norepinephrine. Hyperreactive pressor responses to infusions of norepinephrine were apparent on the first day of overt illness; the hemorrhagic dermal reactions appeared 5 to 7 days after the onset of illness. No increase in cardiovascular reactivity to catecholamines developed in control subjects in whom sandfly fever was induced or in subjects that failed to manifest overt illness after challenge with viable Salmonella typhosa. The cardiovascular hyperreactivity during typhoid fever could not be attributed to shifts in base-line arterial blood pressure or inability to detoxify catecholamines; the consistent thrombocytopenia during typhoid fever, in conjunction with prior platelet studies, suggests that platelet injury may participate.

Although the alterations in cardiovascular reactivity to catecholamines during typhoid fever resembled those in intact experimental animals given endotoxin, additional observations required reconciliation with this interpretation. a) The administration of single iv doses of endotoxin to normal subjects sufficient to evoke febrile and toxic reactions as severe as those seen during the early phase of typhoid fever failed to induce cardiovascular hyperreactivity to catecholamines. b) Intradermal injection of mixtures of endotoxin with epinephrine in normal subjects did not elicit hemorrhagic lesions. c) Cardiovascular hyperreactivity to catecholamines persisted 1 or more weeks into the afebrile convalescent phase of typhoid fever. $d$ ) Cardiovascular hyperreactivity to catecholamines failed to appear during tularemia, a gram-negative bacterial infection clinically similar to typhoid fever.
The possibility is considered that typhoid fever evokes alterations in host reactivity permitting the $S$. typhosa endotoxin to enhance cardiovascular reactivity to catecholamines by release of substances whose activity persists after subsidence of the endotoxemia. The contribution of vasoactive factors released from sites of intestinal inflammation remains to be defined.

\section{Acknowledgments}

The authors express their deepest appreciation to the volunteers who contributed so faithfully to these studies; to Mr. Paul Sharpley, who assisted in the care of these patients; to Mr. James W. Curran, Commissioner of the Maryland Department of Correction; to Mr. William F. Steiner, Chief Warden of the Maryland House of Correction; and to the other officials of the Maryland House of Correction for their generous co-operation and interest, without which these studies could not have been accomplished.

\section{References}

1. Hornick, R. B., T. E. Woodward, M. J. Snyder, L. J. Morse, and F. R. McCrumb, Jr. Studies on typhoid fever induced in volunteers. I. Clinical manifestations. In preparation.

2. Greisman, S. E., R. B. Hornick, F. A. Carozza, Jr., and T. E. Woodward. The role of endotoxin during typhoid fever and tularemia in man. I. Acquisition of tolerance to endotoxin. J. clin. Invest. 1963, 42, 1064.

3. Gilbert, R. P. Mechanisms of the hemodynamic effects of endotoxin. Physiol. Rev. 1960, 40, 245.

4. Thomas, L. The role of epinephrine in the reactions produced by the endotoxins of gram-negative bacteria. I. Hemorrhagic necrosis produced by epinephrine in the skin of endotoxin-treated rabbits. J. exp. Med. 1956, 104, 865.

5. Zweifach, B. W., A. L. Nagler, and L. Thomas. Role of epinephrine in the reactions produced by the endotoxins of gram-negative bacteria. II. The changes produced by endotoxin in the vascular reactivity to epinephrine, in the rat mesoappendix and the isolated, perfused rabbit ear. J. exp. Med. 1956, 104, 881.

6. Greisman, S. E., and C. L. Wisseman, Jr. Studies on rickettsial toxins. IV. Cardiovascular functional abnormalities induced by Rickettsia mooseri toxin in the white rat. J. Immunol. 1958, 81, 345.

7. Gourzis, J. T., M. W. Hollenberg, and M. Nickerson. Involvement of adrenergic factors in the effects of bacterial endotoxin. J. exp. Med. 1961, 114, 593.

8. Nagler, A. L., and B. W. Zweifach. Pathogenesis of experimental shock. II. Absence of endotoxic activity in blood of rabbits subjected to graded hemorrhage. J. exp. Med. 1961, 114, 195. 
9. Buccino, R., J. Lingley, and J. Israel. Evaluation of the epinephrine skin test as a biological assay for endotoxin. Proc. Soc. exp. Biol. (N. Y.) 1962, 110, 724.

10. Greisman, S. E. The reaction of the capillary bed of the nailfold to the continuous intravenous infusion of levo-nor-epinephrine in patients with normal blood pressure and with essential hypertension. J. clin. Invest. 1954, 33, 975.

11. Greisman, S. E. Capillary observations in patients with hemorrhagic fever and other infectious illnesses. J. clin. Invest. 1957, 36, 1688.

12. Wintrobe, M. M. Clinical Hematology. Philadelphia, Lea \& Febiger, 1951, p. 239.

13. Thomas, L., B. W. Zweifach, and B. Benacerraf. Mechanisms in the production of tissue damage and shock by endotoxins. Trans. Ass. Amer. Phycns 1957, 70, 54.

14. Janoff, A., A. L. Nagler, S. Baez, and B. W. Zweifach. Pathogenesis of experimental shock. III. A lethal factor in the blood of rabbits following occlusion of the superior mesenteric artery. J. exp. Med. 1961, 114, 205.

15. Des Prez, R. M., H. I. Horowitz, and E. W. Hook. Effects of bacterial endotoxin on rabbit platelets. I. Platelet aggregation and release of platelet factors in vitro. J. exp. Med. 1961, 114, 857.

16. Von Euler, U. S., and F. Lishajko. Improved technique for the fluorimetric estimation of catecholamines. Acta physiol. scand. 1961, 51, 348.

17. Armstrong, M. D., A McMillan, and K. N. F. Shaw. 3-Methoxy-4-hydroxy-d-mandelic acid, a urinary metabolite of norepinephrine. Biochim. biophys. Acta (Amst.) 1957, 25, 422.
18. Webster, M. E., J. F. Sagin, M. Landy, and A. G. Johnson. Studies on the O antigen of Salmonella typhosa. I. Purification of the antigen. J. Immunol. 1955, 74, 455.

19. Boivin, A., and L. Mesrobeanu. Recherches sur les antigènes somatiques et sur les endotoxines des bactéries. I. Considérations générales et exposé des techniques utilisées. Rev. Immunol. (Paris) 1935, 1, 553.

20. Greisman, S. E., T. E. Woodward, R. B. Hornick, and M. J. Snyder. Role of endotoxin in typhoid fever. Bull. N. Y. Acad. Med. 1961, 37, 493.

21. Fritz, H., K. E. Hagstam, and B. Lindqvist. Local reaction to epinephrine injected intradermally in man-a sign of endotoxinaemia? Acta med. scand. 1962, 172, 463.

22. Hardisty, R. M., and R. S. Stacey. 5-Hydroxytryptamine in normal human platelets. J. Physiol. 1955, 130, 711.

23. Greisman, S. E., H. N. Wagner, Jr., M. Iio, R. B. Hornick, and T. E. Woodward. Suppression of endotoxin tolerance during typhoid fever and tularemia in man. J. clin. Invest. 1963, 42, 940.

24. Greisman, S. E., R. B. Hornick, F. A. Carozza, Jr., and T. E. Woodward. Effect of endotoxin tolerance on human typhoid fever. Trans. Ass. Amer. Phycns 1962, 75, 170.

25. Feldberg, W., and C. C. Toh. Distribution of 5-hydroxytryptamine (serotonin, enteramine) in the wall of the digestive tract. J. Physiol. 1953, 119, 352.

26. Resnick, R. H., and S. J. Gray. Distribution of serotonin (5-hydroxytryptamine) in the human gastrointestinal tract. Gastroenterology 1961, 41, 119. 